\title{
Pengaruh Gaya Kepemimpinan Islami, Budaya Organisasi Islami dan Insentif terhadap Produktivitas Kerja Karyawan PT Yanmar Indonesia
}

\author{
Muhamad Ekhsan \\ Universitas Pelita Bangsa \\ muhamad.ekhsan@pelitabangsa.ac.id
}

\section{Roni Mariyono}

Universitas Pelita Bangsa

ronimariyono45@gmail.com

\begin{abstract}
Abstrak
This study aims to examine whether there is an influence of Islamic leadership style, Islamic organizational culture and incentives to the work productivity of PT. Yanmar Indonesia. The population in this study were employees who worked with PT Yanmar Indonesia section totaling 97. The sampling method used was nonprobability sampling, namely the saturated sampling method. This research uses the SPSS program. The results of this study prove that there is a positive and significant influence between Islamic leadership style and work productivity, there is a positive and significant influence between Islamic organizational culture and work productivity, there is a positive and significant effect between incentives and work productivity.
\end{abstract}

Kata Kunci Islamic leadership style, Islamic organizational culture, incentives, work productivity

\section{PENDAHULUAN}

Persaingan yang terjadi saat ini antar perusahaan satu dengan perusahaan lainnya telah menunjukkan bahwasannya perusahaan saat ini dituntut untuk selalu meningkatkan produktifitas kerjanya agar tidak tertinggal dengan kondisi zaman yang semakin berkembang. Seorang karyawan atau sumber daya manusia menduduki sebuah peranan yang sangat tinggi terhadap kemajuan atau keberlangsungan sebuah organisasi atau perusahaan. Berhasil atau gagalnya sebuah perusahaan ataupun organisasi dalam mencapai sebuah tujuan perusahaan tergantung pada kemampuan sumber daya manusia atau karyawan didalam melaksanakan tugas-tugas yang diembankan kepada karyawannya.( Oktavia et al., 2017 ).

Meningkatnya persaingan industri di era modern sekarang ini menjadi alasan mengapa sumber daya manusia itu sangatlah penting perannya dalam perkembangan sebuah perusahaan. Sukses tidaknya suatu perusahaan dapat dilihat dari aspek sumber daya manusia yang ada dalam lingkup perusahaan tersebut. Produktivitas yang baik hanya bisa tercipta dari sumber daya manusia yang handal. Setiap perusahaan pasti 
menginginkan seluruh karyawannya bisa terampil, kompeten, disiplin, serta bertanggung jawab terhadap pekerjaannya.

PT. Yanmar Indonesia merupakan perusahaan alat berat pertanian ( agraria ) yang terkemuka di dunia, dimana produknya berupa Tractor baik roda dua maupun roda empat, genset, pompa air, mesin tanam dan mesin panen padi. Saat ini Yanmar diesel telah mensuplai alat - alat pertanian diseluruh penjuru dunia dan kualitas produk Yanmar telah diakui beberapa konsumen di seluruh negara. Keberadaan Yanmar Diesel mendapatkan respon yang positif di beberapa negara, karena Yanmar ingin merubah paradigma sebagian besar masyarakat yang pada zaman terdahulu masih memakai alat pertanian manual atau kuno dengan alat - alat pertanian modern. Kendati demikian, Yanmar juga menghadapi tantangan yang sangat besar karena sejalannya waktu banyak sekali perusahaan - perusahaan sejenis yang memproduksi alat - alat yang sama. Namun keadaan tersebut tidak dijadikan hambatan, melainkan dijadikan tantangan untuk bisa mendobrak trend alat agraria modern.

Produktivitas kerja karyawan merupakan masalah yang hangat dan tidak akan ada habisnya untuk dibahas. Permasalahan yang terkait dalam produktivitas juga merupakan isu strategis bagi perusahaan yang memprogram sumber daya manusia. Banyak aspek internal dan eksternal yang mendukung terciptanya produktivitas kerja yang efektif dan efisien dalam suatu perusahaan. Apalagi jika dikaitkan dengan masalah globalisasi yang melanda saaat ini yang dampaknya bisa kita rasakan.

Secara umum produktivitas adalah perbandingan rasio antara input dengan output. Penggunaan rasio ini harus memperhatikan aspek karyawan ( kualitas dan jumlah ) aspek gaya kepemimpinan ( pengarahan dan pembinaan ), aspek budaya maupun aspek sasaran kerja lainnya yang harus dicapai disamping kapasitas mesin pengolahannya. Karena faktor manusia merupakan faktor produktivitas kerja yang terpenting, maka dalam pengelolaanya harus berbeda dengan pengelolaan faktor - faktor yang lain. Para karyawan itu adalah manusia yang mempunyai pribadi yang beraneka ragam yang harus dihormati dan dihargai pada harkat dam martabatnya.

Peningkatan produktivitas karyawan dalam sebuah perusahaan bisa dilihat serta ditentukan melalui output kinerja seorang karyawan (Karsono et al,. 2017 ). Kinerja sendiri merupakan output karyawan, baik secara kualitas kerja dan kuantitas kerja yang didapatkan dari seorang karyawan didalam menyelesaikan tugas yang diembannya dengan rasa penuh tanggung jawab dan kehati - hatian.

Produktivitas karyawan merupakan aspek yang penting bagi perusahaan untuk mendukung organisasi dalam mencapai tujuan (Luftim, 2014). Jadi, sumber daya manusia diharapkan melalui ketrampilan, perilaku dan sikap dapat mencapai produktivitas yang dibutuhkan dalam organisasi.

Berdasarkan hasil dari laporan produksi PT. Yanmar Indonesia selama satu tahun terakhir belakangan diketahui bahwasannya target produksi tidak pernah tercapai dari target rencana yang telah ditetapkan, hal ini karena dipengaruhi oleh beberapa faktor. Berikut ini adalah laporan data produksi PT. Yanmar Indonesia selama kurun waktu satu tahun terakhir dari bulan januari tahun 2019 sampai dengan bulan maret tahun 2020. 


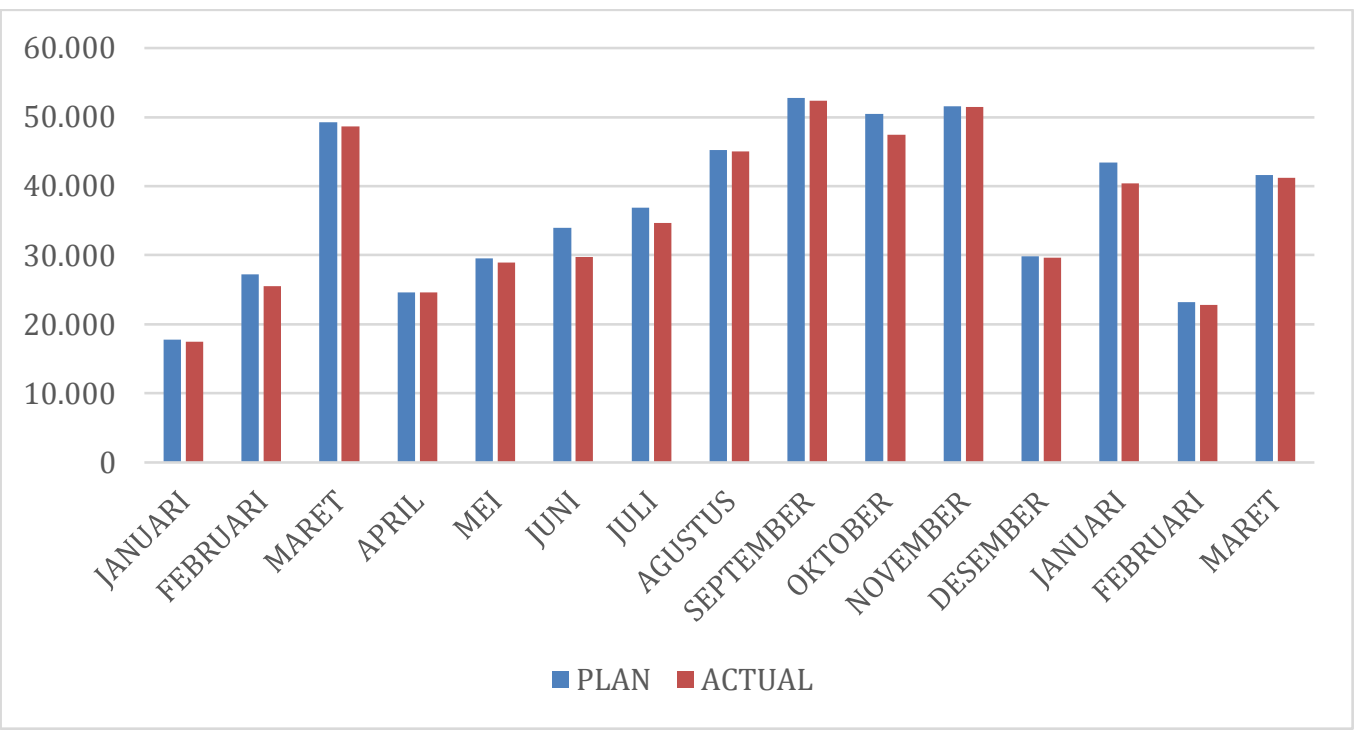

Gambar 1. Data Target Produksi PT. Yanmar Indonesia Januari 2019 - Maret 2020.

Berdasarkan gambar 1 diatas menunjukan penurunan target produksi bulan Januari 2019 sampai bulan Maret 2020. Penurunan produksi ini sangat merugikan bagi perusahaan, yang mana terjadi dari berbagai aspek atau faktor-faktor tertentu di lingkungan PT Yanmar Indonesia.

Sumber daya manusia sendiri merupakan suatu aset terbesar yang dimiliki sebuah organisasi atau perusahaan, karenanya karyawan disini memiliki sebuah bakat dan kemampuan tersendiri serta memiliki sebuah kreatifitas yang tentunya dibutuhkan oleh organisasi dalam hal mencapai tujuan organisasi (Fauzan \& Fatiyah, 2017). Ditengah ketatnya persaingan antara perusahaan satu dengan perusahaan lainnya saat ini, seorang sumber daya manusia diharapkan mampu memiliki sebuah komitmen yang besar terhadap organisasinya supaya dapat mencapai produktivitas kerja yang maksimal untuk terus andil besar didalam memajukan sebuah organisasi.

Kepemimpinan yang berbasis spiritual Islami saat ini seringkali menjadi sebuah topik hangat yang sering menjadi perbincangan dalam berbagai sektor publik. Seperti halnya didalam sektor industri, sektor perdagangan atau perniagaan, sektor perindustrian dan masih banyak sektor - sektor lainnya termasuk didalam sektor pemerintahan. Secara garis besar kepemimpinan yang berbasis spiritual islam atau islamic leadership terdapat empat elemen, yaitu shiddiq, amanah, tabhligh, fathana. Seorang pemimpin apabila menerapkan empat elemen tersebuat niscanya akan memberikan dampak positif yang menyeluruh dalam perusahaan tersebut (Arvian, 2009).

Faktor yang diduga mampu menciptakan sebuah produktivitas kerja karyawan secara optimal diantaranya penerapan gaya kepemimpinan yang berbasis islami (Harahap, 2016). Karakter dalam pemimpin yang berbasis spiritual islam selalu mengedepankan keadilan, kejujuran, selalu mendengarkan bawahan, berilmu dan tidak meminta minta jabata. Seorang pemimpin dikatan sukses ketika mampu mengelola organisasinya untuk mengantisipasi dan sanggup membawa kepada tujuan dalam jangka waktu yang telah ditetapkan. Seorang pemimpin dalam sejarah teori seorang pemimpin telah dijelaskan bahwasannya kepemimpinan yang sangat baik adalah model atau gaya 
kepemimpinan yang dicontohkan dalam ajaran agama islam. Model kepemimpinan yang disebut sebagai Propethic leadership contoh nyatanya adalah manusia teragung sepanjang sejarah kemanusiaan yaitu Rasullullah SAW .

Kepemimpinan dalam bahasa arab disebut dengan khilafah (Aziz et al., 2014). Kepemimpinan yang berbasis spiritual islam dalam sebuah organisasi diperoleh berdasarkan sumber - sumber islamiyang kemudian dipraktekkan di dalam organisasi melalui kepercayaan dan aplikasi secara islami berdasarkan Al-Qur'an dan Sunnah. Pemimpin yang menerapkan gaya spiritual islami selalu mengedepankan Mencintai kebenaran, Menjaga Amanah, Ikhlas dalam mengabdi, Baik dalam Pergaulan serta bijaksana dalam memimpin.

Seorang pemimpin yang menerapkan gaya kepemimpinannya secara ajaran spiritual islami selalu mempunyai anggapan bahwasannya didunia ini hanyalah merupakan sebuah perjalanan kehidupan yang didalamnya hanyalah menanam benih benih kebaikan atau kemanfaatan bagi sesama manusia yang akhir nantinya akan dipanen di akhirat kelak (Adiba, 2018). Gaya kepemimpinan dalam islam tidak terdapat penggolongan terhadap tipe - tipe gaya kepemimpinan selayaknya gaya kepemimpinan yang bersifat konvensional. Namun, didalam ajaran islam ditentukan ajaran seorang pemimpin yang sejalan dengan Al quran dan Hadist nabi. Gaya kepemimpinan dalam islam adalah gaya kepemimpinan informal yang artinya seorang pemimin tidak resmi dalam pengangkatannya. Keberagaman suku budaya dan agama dalam ajaran islam membagi sikap keteladanan seorang pemimpin sebagai Sikap terhadap golongan Islam, Sikap sesama ummat Islam, dan sikap sebagai pemimpin bangsa.

Budaya organisasi yang berbasis Islami di lingkungan perusahaan terdapat pilar dasar budaya islam diantaranya yaitu Gerakan Thaharah atau menciptakan lingkungan kerja yang bersih dan bebas dari asap rokok, Gerakan Shalat secara berjamaah, dan gerakan berpakaian Islami bagi karyawan perempua. Budaya organisasi menjadi salah satu faktor yang diduga dapat menciptakan suatu kinerja karyawan yang baik. Budaya organisasi cenderung diciptakan oleh seluruh anggota dalam organisasi itu sendiri, ketika budaya tersebut dapat berkembang dengan baik maka terciptanya lingkungan kerja yang menyenangkan(Fauzan dan Fatiyah, 2017).

Budaya organisasi merupakan landasan dasar sebuah nilai dan asumsi bersama yang mengatur bagaiman seorang karyawan didalam berperilaku atas problematika dan peluang didalam sebuah organisasi (Mashudi, 2014). Budaya organisasi yang sangat kuat memiliki potensi untuk bisa meningkatkan kinerja karyawan, begitu pula sebaliknya apabila sebuah budaya organisasinya sudah lemah akan mengakibatkan kinerjanya menurun. Menurut ajaran perspektif islam, tujuan didirikan suatu organisasi harus bisa sejalan dan seirama dengan tujuan awal hidup manusia sebagai khalifah atau utusan Allah di muka bumi ini ( Firdaus, 2018 ).

Salah satu jalan untuk mengoptimalkan kinerja karyawan secara optimal yaitu dengan pemberian balas jasa insentif dalam hal ini secara tidak sengaja diberikan kepada karyawan agar didalam diri mereka timbul sebuat semangat besar untuk meningkatkan prestasi kerja karyawan, sehingga produktifitas dan kinerjanya meningkat. Pemberian insentif didalam suatu perusahaan memegang peran penting karena diyakini akan dapat mengatasi berbagai permasalahan ditempat kerja yang semakin kompleks. Rendahnya kinerja karyawan yang dikarenakan semangat gairah kerja karyawan yang belum sepenuhnya optimal baik. Selain itu, disebabkan karena masih rendahnya atau kurangnya 
motivasi kerja, status atau posisi karyawan yang masih belum jelas statusnya serta tidak didukung dengan adanya tambahan pendapatan atau input bagi karyawan selain gaji pokok yang diterimanya.

Pemberian insentif diharapkan mampu meningkatkan kinerja karyawan secara optimal. Selain itu, diharapkan produktivitas meningkat, loyalitas tinggi, disiplin meningkat, dan adanya rasa tanggung jawab terhadap jabatan atau pekerjaan yang di embannya. Semakin baik mutu kepemimpinan bagi karyawan, maka memperoleh kesempatan untuk menambah pendapatan. Pembahasan mengenai insentif dijelaskan dalam Al-qur'an Q.S Al- Jaatsiyah ayat 45:22 'Dan Allah menciptakan langit dan bumi dengan tujuan yang benar dan agar dibalasi tiap-tiap diri terhadap apa yang dikerjakannya, dan mereka tidak akan dirugikan'. Selain itu juga disetiap jiwa diberikan sebuah balasan atas apa kebaikan dan kejahatan yang dilakukannya selama di muka bumi ini, balasan mereka tidaklah dikurangi sedikitpun.

Berdasarkan fenomena yang telah disampaikan, maka rumusan masalah yang diangkat pada penelitian ini adalah, apakah Gaya Kepemimpinan Islami berpengaruh terhadap produktivitas kerja, apakah Budaya Organisasi Islami berpengaruh terhadap produktivitas kerja, apakah insentif berpengaruh terhadap produktivitas kerja. Hasil penelitian ini harapannya dapat berguna sebagai bahan masukan bagi pihak manajemen khususnya dan pihak lain yang tertarik kajian Gaya kepemimpinan Islami, Budaya Organisasi berbasis islami, Insentif dan Produktivitas kerja.

\section{LANDASAN TEORI Produktivitas Kerja}

Produktivitas kerja karyawan memiliki pengaruh pada tujuan yang ingin dicapai oleh perusahaan. Maka dari itu setiap perusahaan harus melakukan pengukuran pada produktivitas kerja karyawan. Produktivitas kerja adalah kemampuan memperoleh manfaat sebesar-besarnya dari sarana dan prasarana yang tersedia dengan menghasilkan output yang optimal, kalau mungkin yang maksimal(Siagian, 2002). Produktivitas merupakan hal yang sangat penting bagi para karyawan yang ada di perusahaan. Peningkatan produktivitas kerja diharapkan akan terlaksana secara efektif dan efisien, sehingga diperlukan dalam pencapaian tujuan yang sudah ditetapkan dan untuk mengukur produktivitas kerja diperlukan indikator sebagai berikut (Mangkunegara, 2016) :

a. Kualitas Kerja.

b. Kuantitas Kerja.

c. Pelaksanaan Tugas.

d. Tanggung Jawab.

\section{Gaya Kepemimpinan Islami}

seorang pemimpin yang menerapkan gaya pemimpin secara ajaran spiritual islami selalu mempunyai anggapan bahwasannya di dunia ini hanyalah merupakan suatu perjalanan kehidupan yang didalamnya hanyalah menanam benih - benih kebaikan atau kemanfaatan bagi sesama yang akhir nantinya akan dipanen di akhirat kelak (Adiba, 2018). Gaya kepemimpinan yang dimuat didalam pengertian kali ini yaitu gaya pemimpin yang berbasis spiritual islami dimana sebuah kegiatan atau aktifitas yang bertujuan untuk menuntun seseorang, membimbing seseorang, kemudian menunjukkan mana jalan kebenaran yang di ridhoi oleh Allah SWT. Agama Islam mengajarkan bahwa 
kepemimpinan yang baik adalah kepemimpinan yang selalu berpegang kepada Al-Qur'an dan Hadist. Indikator untuk mengukur kepemimpinan Islam menurut Wijayanti dan Meftahudin (2016) dengan menggunakan indikator yaitu:

a. Ash-Shidq

b. Al-amanah atau kepercayaan,

c. Al-Fathanah yaitu kecerdasan

d. At-Tabligh

\section{Budaya Organisasi Islami}

Prinsip budaya organisasi Islami mengedepankan prinsip-prinsip etika dan karakter-karakter mulia yang dalam Islam disebut dengan akhlaqul karimah (Usman, 2015). Budaya organisasi telah dicontohkan oleh Nabi Muhammad SAW dengan menanamkan nilai-nilai akhlakul karimah dalam memimpin keluarga, kelompok, umat dan Negara(Fahmi et al., 2014). Nabi Muhammad SAW mencontohkan bagaimana menciptakan budaya organisasi dengan perilaku/akhlakul karimah yang mengedepankan kebersamaan, persaudaraan dan kesetaraan. Indikator budaya organisasi berbasis islami yang didapat dari nilai - nilai organisasi dalam Al quran adalah sebagai berikut (Muchlis, 2012) :

a. Komitmen dalam perjanjian kerja.

b. Profesional dalam bekerja.

c. Amanah dan bertanggungjawab.

d. Loyalitas dalam bekerja.

\section{Insentif}

Insentif adalah suatu penghargaan dalam bentuk uang yang di berikan oleh pihak pemimpin organisasi kepada karyawan agar mereka bekerja dengan motivasi yang tinggi dan prestasi dalam mencapai tujuan-tujuan organisasi atau dengan kata lain, insentif kerja merupakan pemberian uang diluar gaji yang dilakukan oleh pihak pemimpin organisasi sebagai pengakuan terhadap prestasi kerja dan kontribusi karyawan kepada organisasi (AA. Anwar Prabu Mangkunegara, 2011). Indikator pemberian insentive kepada karyawan (Sarwoto, 2010) yaitu :

a. Pemberian bonus financial kepada karyawan.

b. Pemberian komisi.

c. Pemberian pujian.

d. Pemberian tanda jasa karyawan.

\section{METODOLOGI PENELITIAN}

Penelitian ini merupakan jenis penelitian kuantitatif, yaitu penelitian dengan cara pengolahan data hasil penelitian menggunakan pendekatan statistik. Pendekatan ini bersifat empiris, obyektif, terukur, rasional, dan sistematis serta memberikan informasi atau penemuan mengenai hubungan antara dua variabel atau lebih, dengan tujuan menguji hipotesis yang telah ditetapkan (Sugiyono, 2013). Penelitian ini dilakukan dengan maksud untuk melihat adakah pengaruh penerapan gaya kepemimpinan islami, budaya organisasi islami dan insentif terhadap produktifitas kerja karyawan PT. Yanmar Indonesia. Adapun Pengumpulan data dengan menggunakan kuesioner. 
Populasi adalah sekelompok orang, yang memiliki sebuah karakteristik dan akan dijadikan sebuah objek daripada sebuah penelitian (Suryani \& Hendryadi, 2015). Populasi didalam penelitian ini adalah karyawan PT. Yanmar Indonesia pada departemen Technical. Teknik pengambilan sampelnya dengan sensus, hal ini dikarenakan seluruh populasi dijadikan sampel sebanyak 97 karyawan.

Pengujian data yang digunakan dalam penelitian ini meliputi uji validitas, reliabilitas, analisis regresi linear berganda, uji t untuk menguji dan membuktikan hipotesis penelitian, uji f dan koefisien determinasi.

\section{HASIL PENELITIAN}

\section{Uji Statistik T}

Uji t digunakan untuk menentukan seberapa jauh pengaruh satu variabel independen secara individual dalam menerangkan variasi variabel dependen. Hipotesis akan diuji dengan taraf signifikan 5\% (Ghozali, 2013)

Hasil uji t untuk variable gaya kepemimpinan islami terhadap produktivitas kerja karyawan menunjukkan hasil nilai signifikansi sebesar 0,004 nilai ini lebih kecil dari $0,05(0,004<0,05)$ dan thitung lebih besar dari t tabel $(2,966>1,984)$. Nilai t positif menunjukkan bahwa variable Gaya Kepemimpinan mempunyai hubungan yang searah dengan produktivitas kerja. Maka kesimpulan yang dapat diambil Ha1 diterima dan Ho1 ditolak. Hal ini menunjukkan gaya kepemimpinan islami berpengaruh positif dan signifikan terhadap produktivitas kerja karyawan PT. Yanmar Indonesia. Hasil penelitian ini mendukung hasil penelitian terdahulu yang dilakukan oleh Moh. Mukhsin (2017) menyimpulkan bahwa adanya adanya pengaruh yang positif dan signifikan antara kepemimpinan islami terhadap produktivitas kerja karyawan pada pondok pesantren AlHikmah Ciruas - Serang

Hasil uji t untuk variable budaya organisasi berbasis islami terhadap produktivitas kerja karyawan menunjukkan hasil nilai signifikansi sebesar 0,001 nilai ini lebih kecil dari $0,05(0,001<0,05)$ dan t hitung lebih besar dari t tabel $(3,397>1,984)$. Nilai $t$ positif menunjukkan bahwa variable Budaya Organisasi Islami mempunyai hubungan yang searah dengan produktivitas kerja. Maka kesimpulan yang dapat diambil Ha2 diterima dan Ho2 ditolak. Hal ini menunjukkan budaya organisasi islami berpengaruh positif dan signifikan terhadap produktivitas kerja karyawan PT. Yanmar Indonesia. Hasil penelitian ini mendukung hasil penelitian terdahulu yang dilakukan oleh Wakhidah Nur Rohmatul Laili (2018) menyimpulkan bahwa adanya pengaruh yang positif dan signifikan antara budaya organisasi syariah terhadap produktivitas kerja karyawan pada PT. Hasanah Mulia Investama.

Hasil uji t untuk variable insentif terhadap produktivitas kerja karyawan menunjukkan hasil nilai signifikansi sebesar 0,004 nilai ini lebih kecil dari 0,05 ( 0,004 < 0,05 ) dan t hitung lebih besar dari t tabel ( 2,986>1,984). Nilai t positif menunjukkan bahwa variable Insentif mempunyai hubungan yang searah dengan produktifitas kerja. Maka kesimpulan yang dapat diambil Ha3 diterima dan Ho3 ditolak. Hal ini menunjukkan bahwa insentive berpengaruh positif dan signifikan terhadap produktivitas kerja karyawan PT. Yanmar Indonesia. Hasil penelitian ini mendukung hasil penelitian terdahulu yang dilakukan oleh Siti Qamariyah dan Fadllan (2017) menyimpulkan bahwa 
pengaruh yang signifikan antara pemberian Insentive terhadap produktivitas kerja karyawan pada PT. Bank Pembiayaan Rakyat Syariah Bhakti Sumekar Sumenep.

\section{Uji Statistik F}

Uji $\mathrm{F}$ dimaksud untuk menunjukkan bahwa model regresi signifikan atau gaya kepemimpinan islami, budaya organisasi islami, insentif secara bersama-sama dapat dipakai untuk memprediksi produktivitas. Berikut adalah data uji statistik F

\section{Tabel 1. Uji Statistik F}

ANOVA $^{\mathrm{a}}$

\begin{tabular}{|c|c|c|c|c|c|c|}
\hline \multicolumn{2}{|c|}{ Model } & Sum of Squares & $\mathrm{df}$ & Mean Square & $\mathrm{F}$ & Sig. \\
\hline \multirow[t]{3}{*}{1} & Regression & 767,833 & 3 & 255,944 & 47,712 &, $000^{\mathrm{b}}$ \\
\hline & Residual & 498,889 & 93 & 5,364 & & \\
\hline & Total & 1266,722 & 96 & & & \\
\hline
\end{tabular}

a. Dependent Variable: produktivitas kerja

b. Predictors: (Constant), insentive, gaya kepemimpinan islami, budaya organisasi islami

Sumber : Data Primer yang diolah ( 2020 ).

Berdasarkan tabel 1 di atas hasil uji $\mathrm{F}$ menunjukkan bahwa model regresi signifikan atau gaya kepemimpinan islami, budaya organisasi islami, insentif, secara bersama-sama dapat dipakai untuk memprediksi produktivitas kerja PT. Yanmar Indonesia, dibuktikan pada tabel 4 diperoleh nilai F hitung $=47,712$ lebih besar dari nilai $\mathrm{F}$ tabel $=2,701$, dengan nilai signifkansi lebih kecil dari nilai standar error yang ditetapkan yaitu $0,05(0,000<0,05)$ maka Ho ditolak dan Ha diterima. Hasil ini dapat dikatakan bahwa gaya kepemimpinan islami, budaya organisasi islami dan insentif dapat dipakai untuk memprediksi produktivitas kerja PT Yanmar Indonesia.

\section{Koefisien Determinasi ( $R 2$ ).}

Koefisien determinasi bertujuan untuk mengetahui seberapa besar kemampuan variable independen menjelaskan variable dependen. Hasil nilai koefisien determinasi dapat dilihat pada tabel berikut ini

Tabel 2 Hasil Uji Koefisien Determinasi ( Uji R2 ).

\begin{tabular}{|l|r|r|r|c|}
\hline \multicolumn{1}{l|}{} & & & \multicolumn{4}{|c|}{ Model Summary } \\
Model & $\mathrm{R}$ & $\mathrm{R}$ Square & $\begin{array}{c}\text { Adjusted R } \\
\text { Square }\end{array}$ & $\begin{array}{c}\text { Std. Error of the } \\
\text { Estimate }\end{array}$ \\
\hline 1 &, $779^{\mathrm{a}}$ &, 606 &, 593 & 2,31612 \\
\hline
\end{tabular}

a. Predictors: (Constant), insentive, gaya kepemimpinan islami, budaya organisasi berbasis islami

Sumber : Data Primer yang diolah, ( 2020 ).

Berdasarkan tabel 2 diatas dapat diketahui bahwa nilai Adjusted R Square sebesar 0,593. Hal ini bearti 59,3\% gaya kepemimpinan islami, budaya organisasi islami dan insentif berpengaruh terhadap produktivitas kerja karyawan, sedangkan sisanya yaitu $30,4 \%$ produktivitas kerja dipengaruhi oleh variable - variable lainnya yang tidak diteliti dalam penelitian ini. 


\section{Analisis Regresi Linear Berganda}

Merupakan metode statistik untuk menguji pengaruh antara satu variable terikat dan beberapa variable bebas adalah dengan menggunakan analisis regresi linear berganda. Dengan menggunakan bantuan perangkat lunak SPSS For windows 23.0. karena peneliti menggunakan tiga variable bebas dan satu variable terikat, maka peneliti menggunakan analisis regresi linear berganda, tujuannya untuk menguji pengaruh satu variable terikat dan beberapa variable bebas dengan menggunakan regresi berganda.

Tabel 3 Hasil Analisis Uji Regresi Linear Berganda

\begin{tabular}{|c|c|c|c|c|c|}
\hline \multicolumn{6}{|c|}{ Coefficients $^{a}$} \\
\hline \multirow[b]{2}{*}{ Model } & \multicolumn{2}{|c|}{ Unstandardized Coefficients } & \multirow{2}{*}{$\begin{array}{c}\text { Standardized Coefficients } \\
\text { Beta }\end{array}$} & \multirow[b]{2}{*}{$\mathrm{t}$} & \multirow[b]{2}{*}{ Sig. } \\
\hline & $\mathrm{B}$ & Std. Error & & & \\
\hline 1 (Constant) & 2,897 & 2,243 & & 1,292 & 200 \\
\hline gaya kepemimpinan islami & ,266 & ,090 & ,30 & 2,966 & ,004 \\
\hline budaya organisasi islami & ,414 & ,122 & ,36 & 3,397 & 001 \\
\hline insentive & ,224 & 075 & 2 & 2,986 & ,004 \\
\hline
\end{tabular}

a. Dependent Variable: produktivitas kerja

Sumber : Data Primer yang diolah, ( 2020 ).

Berdasarkan tabel 3 diatas dapat diketahui hasil uji regresi linear berganda sebagai

berikut : $\mathrm{Y}=\mathrm{a}+\mathrm{Bx}$ atau 2,897 +0,266 $\mathrm{X}_{1}+0,414 \mathrm{X}_{2}+0,224 \mathrm{X}_{3}$

Model tersebut menunjukkan bahwa :

1. Constant $=2,897$.

Nilai konstan positif menunjukkan pengaruh positif variable independen ( gaya kepemimpinan islami, budaya organisasi islami dan insentif ), bila variable independen naik atau berpengaruh, maka variable produktivitas kerja karyawan akan naik sebesar 2,897 atau terpenuhi.

2. Koefisien Variable Gaya kepemimpinan Islami = 0,266.

Merupakan nilai koefisien regresi variable gaya kepemimpinan islami terhadap variable produktivitas kerja karyawan artinya jika gaya kepemimpinan islami mengalami kenaikan, maka produktivitas kerja karyawan akan mengalami kenaikan sebesar 0,266 atau $26,6 \%$.

3. Koefisien Variable Budaya Organisasi Islami $=0,414$.

Merupakan nilai koefisien regresi variable budaya organisasi islami terhadap variable produktivitas kerja artinya jika budaya organisasi berbasis islami mengalami kenaikan, maka produktivitas kerja mengalami peningkatan sebesar 0,414 atau 41,4\%. Koefisien bernilai positif artinya antara budaya organisasi berbasis islami dengan produktivitas kerja berhubungan positif. Kenaikan budaya organisasi islami akan mengakibatkan kenaikan pula pada produktivitas kerja karyawan 
4. Koefisien Variable Insentif $=0,224$.

Merupakan nilai koefisien regresi variable insentive terhadap variable produktivitas kerja artinya jika insentive mengalami kenaikan, maka produktivitas kerja mengalami peningkatan sebesar 0,224 atau 22,4\%. Koefisien bernilai positif artinya antara insentif dengan produktivitas kerja berhubungan positif. Kenaikan insentif akan mengakibatkan kenaikan pula pada produktivitas kerja karyawan .

\section{KESIMPULAN}

Berdasarkan hasil pengujian, maka dapat di tarik kesimpulan bahwa secara parsial, Gaya kepemimpinan islami, mempunyai pengaruh yang positif dan signifikan terhadap produktivitas kerja. Budaya organisasi islami mempunyai pengaruh yang positif dan signifikan terhadap produktivitas kerja. Insentif berpengaruh positif dan signifikan terhadap produktivitas kerja. Secara simultan gaya kepemimpinan islami, budaya organisasi islami dan insentif berpengaruh positif dan sigifikant terhadap produktivitas kerja

\section{DAFTAR PUSTAKA}

Adiba, M.E. 2018. Kepemimpinan Islami, Kepuasan Kerja, Komitmen Kerja, dan Loyalitas Kerja Karyawan Bank Syariah Mandiri di Sidoarjo. Al - Uqud: Journal of Islamic Economics. 2 (1): 60-80.

Arvian Arivin \&, V. R. (2009). Islamic Leadership. Jakarta: Bumi Aksara.

Aziz, R dan Shofawati, A. 2014. Pengaruh Kepemimpinan Islami dan Budaya Organisasi Islami terhadap Motivasi Kerja Islami pada UMKM Kulit Magetan. Jurnal Ekonomi Syariah Teori \& Terapan. 1 (6): 393-409

Fauzan, M.O \& Fathiya. 2017. Pengaruh Budaya Organisasi, Gaya Kepemimpinan dan Pengawas terhadap Motivasi serta Dampaknya terhadap Kinerja Pegawai Dinas Pekerjaan Umum (PU) Kabupaten Batang Hari Jambi. Jurnal Manajemen dan Sains. 2 (2): 183-195.

Firdaus, A. 2018. Mengembangkan Siklus Penerapan Sistem Manajemen Kinerja Berbasis Kemaslahatan. Al - Uqud: Journal of Islamic Economics. 2 (1): 94- 120. $1-7$

Ghozali, Imam, "Aplikai Analisis Multivarite dengan SPSS" Edisi Keempat, Badan Penerbit Universitas Diponegoro, Semarang, 2013.

Harahap, S. 2016. Pengaruh Kepemimpinan Islami dan Motivasi Kerja terhadap Kinerja Karyawan pada PT. Bank Syariah Mandiri, Tbk Kantor Cabang Pembantu Sukaramai Medan. Human Falah: Jurnal Ekonomi dan 3 (2): 243-270.

Luftim, C. (2014). The Impact of Strategic Human Resource Management on Organizational Performance, Economia. Seria Management, 2, 374-380.

Mangkunegara, A.A. Anwar Prabu. 2016. Manajemen Sumber Daya Manusia Perusahaan Bandung: Remaja Rosdakarya.

McShane, S., \& Von Glinow, M. (2014). Organizational behavior (Irwin Management Series). 
Muchlis, M Hanafi, et al.(2012).Tafsir Al-Quran Tematik Kerja dan Ketenagakerjaan.Lajnah Pentashihan Mushaf Al-Quran Badan Litbang dan Diklat Kementrian Agama RI 2010

Nawawi, H., \& Hadari, M. M. (1993). Kepemimpinan yang efektif. Gadjah Mada Press.

Oktavia, A., Zulfanetti, Z., \& Yulmardi, Y. (2017). Analisis produktivitas tenaga kerja sektor pertanian di Sumatera. Jurnal Paradigma Ekonomika, 12(2), 49-56.

Sugiyono. 2013. Metodologi Penelitian Bisnis. Edisi Kedua. Bandung: Alfabeta.

Suryani, S., \& Hendryadi, H. (2015). A developing model of relationship among service quality, consumer satisfaction, loyalty and word of mouth in Islamic Banking. AlIqtishad: Jurnal Ilmu Ekonomi Syariah, 7(1), 45-58.

Wijayanti, R. dan Meftahudin. 2016. Pengaruh Kepemimpinan Islami, Motivasi dan Kepuasan Kerja terhadap Kinerja Karyawan dengan Lama Kerja sebagai Variabel Moderating. III Jurnal PPKM. 1 (2): 185-192 